\title{
Stigma and perceived aggression towards schizophrenia in female students of medicine and psychology
}

\author{
Ana Fresán, ${ }^{1}$ Rebeca Robles-García, ${ }^{2}$ Nicolás Martínez-López, ${ }^{1}$ Carlos Alfonso Tovilla-Zárate, ${ }^{3}$ Eduardo Madrigal ${ }^{4}$
}

\begin{abstract}
Subdirección de Investigaciones Clínicas, Instituto Nacional de Psiquiatría Ramón de la Fuente Muñiz, Ciudad de México, México.

2 Dirección de Investigaciones Epidemiológicas y Sociales, Instituto Nacional de Psiquiatría Ramón de la Fuente Muñiz, Ciudad de México, México.

3 División Académica Multidisciplinaria, Universidad Juárez Autónoma de Tabasco, Comalcalco, Tabasco, México.

${ }^{4}$ Dirección General, Servicios de Atención Psiquiátrica, Ciudad de México, México.
\end{abstract}

\section{Correspondence:}

\section{Ana Fresán}

Laboratorio de Epidemiología Clínica, Subdirección de Investigaciones Clínicas, Instituto Nacional de Psiquiatría Ramón de la Fuente Muñiz.

Calz. México-Xochimilco 101, Col. San Lorenzo Huipulco, Del. Tlalpan, C.P. 14370, Ciudad de México, México.

Phone: (55) 4160 - 5069

Email: fresan@imp.edu.mx

Received: 5 July 2018

Accepted: 19 September 2018

\section{Citation:}

Fresán, A., Robles-García, R., Martínez-López, N., Tovilla-Zárate, C. A., \& Madrigal, E. (2018). Stig$\mathrm{ma}$ and perceived aggression towards schizophrenia in female students of medicine and psychology. Salud Mental, $41(5), 207-212$. doi: 10.17711/SM.0185-3325.2018.031

\section{(c) (P) \$}

\begin{abstract}
Introduction. The main attitudes towards people with schizophrenia are fear and rejection, which derive from the idea that patients have no control over their behavior and that they are aggressive, violent, and/or dangerous. Several studies have shown that mental health professionals show negative attitudes towards patients with schizophrenia from the start of their professional training. Objective. To compare the stigmatizing attitudes and perception of aggression of female undergraduate students of medicine and psychology towards people with schizophrenia. Method. Fifty-seven (49.6\%) undergraduate medical students and $58(50.4 \%)$ psychology students in the early semesters of their professional training were included. Both groups answered the Opinion Scale on Mental IIIness and the Public Concept of Aggressiveness Questionnaire (PCA). Results. Over $60 \%$ of the students from both degree courses considered that the individual with schizophrenia described in the vignette could be aggressive, with a higher percentage corresponding to female students enrolled in the medical degree program. In this group, more negative attitudes towards the disease were observed in terms of separatism, restriction, and stigmatization. Discussion and conclusion. It is essential to promote clear, objective information with a biopsychosocial approach to the disease in the syllabus in order to reduce or eliminate stigmatizing beliefs and attitudes regarding schizophrenia acquired prior to professional training.
\end{abstract}

Keywords: Stigma, schizophrenia, medicine, psychology.

\section{RESUMEN}

Introducción. Las principales actitudes hacia las personas con esquizofrenia son de temor y rechazo, las cuales surgen de la idea de que los pacientes no tienen control sobre su comportamiento y que son agresivos, violentos y/o peligrosos. Diversos estudios han señalado que los profesionales de la salud mental muestran actitudes negativas hacia los pacientes con esquizofrenia desde el inicio de su formación profesional. Objetivo. Comparar las actitudes estigmatizadoras y la percepción de agresión de mujeres estudiantes de pregrado de medicina y de psicología hacia las personas con esquizofrenia. Método. Se incluyeron $57(49.6 \%)$ estudiantes de pregrado de medicina y $58(50.4 \%)$ de psicología que cursaban los primeros semestres de su formación profesional. Ambos grupos contestaron la Escala de Opiniones sobre la Enfermedad Mental y el Cuestionario de Concepto Público de Agresividad (CPA). Resultados. Más del $60 \%$ de las estudiantes de ambas carreras consideraron que el sujeto con esquizofrenia descrito en la viñeta podría ser agresivo. De éstas, el mayor porcentaje de alumnas pertenecía a la carrera de medicina. De forma similar, en este grupo se observaron mayores actitudes negativas hacia la enfermedad en términos de separatismo, restricción y estigmatización. Discusión y conclusión. Es necesario promover dentro del currículo académico información clara y objetiva con un enfoque biopsicosocial de la enfermedad con la finalidad de reducir o eliminar las creencias y actitudes estigmatizadoras sobre la esquizofrenia adquiridas antes de la formación profesional.

Palabras clave: Estigma, esquizofrenia, psicología, medicina. 


\section{INTRODUCTION}

The social group to which we belong largely determines the way we perceive the world and people around us (García-Silberman, 1998). However, many of these conceptions are shaped by negative values, which lead to stigma. The conceptualization of stigma has undergone major variations over time, from constructs that emphasized internal psychological processes to more complex formulations incorporating evolutionary, political, and institutional forces and social cultural structures (Yang et al., 2007). According to a more traditional definition, stigma is understood as an attribute that profoundly discredits the individuals who have it, degrading them from normal to corrupt persons (Goffman, 2009). Some social and psychological definitions describe stigma as a mark associated with negative meanings perceived by society (Jones et al., 1984).

The above definitions highlight the emphasis placed on social stereotypes that devalue individuals and their social identity in a particular context, theoretical constructs that have been incorporated into the area of mental illness (Link, Phelan, Bresnahan, Stueve, \& Pescosolido, 1999). These include labeling (when people consider a human difference as significant and assign a label to it), stereotyping (when the incorporation of the belief labels people with negative characteristics), and cognitive separation (when a distinction is made between "us, normal people" and "them, odd people"). From the above, it is possible to conceive stigma towards mental illness as a combination of three central problems: lack of knowledge about the particular disease or person (ignorance), the generation of negative attitudes towards them (prejudice), and the avoidance or exclusion of the person (discrimination) (Corrigan, 2005; Rose, Thornicroft, Pinfold, \& Kassam, 2007; Thornicroft, 2006).

In the area of mental health, the general public has been exposed to mental illnesses -including the most severe ones, such as schizophrenia- through myths, stereotypes, and traditional beliefs. The main attitudes towards people with schizophrenia have been fear and rejection, derived from the public perception that patients have no control over their behavior (García-Silberman, 1998) and that they are aggressive, violent, and/or dangerous (Fresán et al., 2002; Link, Cullen, Frank, \& Wozniak, 1987; Link et al., 1999; Penn et al., 1994; Steadman et al., 1998).

One might think that there are only very few people in the general public who have had a direct, relevant personal exposure to mental illness and that, since they lack objective information about schizophrenia, they have the most negative, stigmatizing attitudes towards patients. However, several studies have shown that health professionals are no exception (Arens, Berger, \& Lincoln, 2009; Fernando, Deane, \& McLeod, 2010; Mental Health Foundation, 2000; Schulze \& Angermeyer, 2003), and that even those engaged in mental health care, such as psychologists, show negative attitudes towards patients with schizophrenia (Arens et al., 2009), which may even be present from the start of their professional training (Fresán, Robles-García, Cota, et al., 2012; Fresán, Robles-García, Martínez, Berlanga, \& Vargas-Huicochea, 2012).

The purpose of this study is therefore to compare the stigmatizing attitudes and perception of aggression of female undergraduate medicine and psychology students towards people with schizophrenia. It was decided to include women only because, although results are not consistent, some reports in the international literature emphasize greater stigma and perception of aggressiveness by women towards patients with schizophrenia (Robles-García, Fresán, Berlanga, \& Martínez, 2013). At the same time, women from these two-degree programs were included due to the high probability that they will care for or come into contact with people with schizophrenia in their professional lives. Early identification of negative attitudes towards mental illness will make it possible to determine, at the start of the training, the educational needs that must be met to reduce the stigma associated with serious mental illnesses such as schizophrenia, because several studies have shown that the stigma towards schizophrenia is high among students enrolled in these degree programs during their last years of training (Magliano et al., 2014). The central hypothesis is that undergraduate psychology students will show fewer negative attitudes and a lower perception of aggressiveness in schizophrenia than female undergraduate medical students due to their interest in the area of mental health at the start of their professional training, in comparison with medical students.

\section{METHOD}

This is a non-experimental, cross-sectional, analytical, homodemic study (Feinstein, 1995). The sample was calculated using the $\mathrm{G}^{*}$ Power statistical program version 3.1.9.2, which stipulated the inclusion of 115 participants and established a medium effect size (.3), with an Alpha probability of .05 and a statistical power of .90 .

\section{Participants}

Recruitment and data information were carried out from January 2012 to January 2013. The sample comprised female undergraduate medicine and psychology students from a metropolitan university in Mexico City, who agreed to participate in the study on a voluntary, anonymous basis and were in the first year of their professional training. Those who did not complete the questionnaire or voluntarily requested their exclusion from the study were eliminated. On the basis of these criteria, a total of 115 women with an average age of $19.9(S D=1.0$, range $=19-26$ years $)$, 
comprising undergraduate medical $(n=57,49.6 \%)$ and psychology students $(n=58,50.4 \%)$, were included. There was no need to eliminate cases due to attrition or incomplete data. This study was approved by the Ethics and Research Committees of the Instituto Nacional de Psiquiatría Ramón de la Fuente and the respective authorities of the university where the study was conducted.

\section{Instruments}

The Opinions about Mental Illness-(OMI) scale was used to evaluate attitudes towards people with serious mental disorders (Ng \& Chan, 2000), using the version for Mexico (OMI-M). The instrument, consisting of 34 self-applicable statements rated by level of agreement (from $1=$ totally disagree to $5=$ totally agree), evaluates six dimensions related to negative attitudes towards mental illness: 1. Separatism entails perceived differences and the desire to keep one's distance from people with mental illnesses; 2. Stereotypes define people with mental disorders based on specific behaviors and a certain intellectual capacity; 3. Restriction evaluates the point of view on the rights of people with mental disorders; 4. Benevolence rates compassion towards people with mental disorders; 5. Pessimistic prediction assesses the perception of the incapacity for improvement and reintegration of people with mental disorders into society, and 6. Stigmatization assesses the perception of mental disorders as a reason for shame and concealment.

The Public Concept of Aggressiveness Questionnaire (PCA) is a self-applicable instrument assessing the percep- tion of the aggressiveness of the patient with schizophrenia, based on the presentation of a clinical vignette of a patient with paranoid schizophrenia with active psychotic symptoms (such as auditory hallucinations, delusions of reference, and active social avoidance). The characteristics presented in the vignettes are used to evaluate the respondent's perception of the presence and severity of the patient's aggressiveness and its different sub-types (verbal, self-directed, towards objects, and heterodirected), as well as their perception of the dangerousness of the patient described in the vignette (Fresán, Robles-García, Saracco, \& Escamilla, 2010).

Both instruments showed adequate values of reliability and validity for their use in Mexican population. The PCA has shown adequate reliability and validity for its use in Mexican population (Fresán, Robles-García, Cota, et al., 2012; Fresán et al., 2010).

\section{Statistical analysis}

The SPSS statistical program version 20.0 was used to analyze the data. The variables included in the study were described, with frequencies and percentages for the categorical ones and with means $(M)$ and standard deviations $(S D)$ for the continuous ones. As hypothesis tests for the comparison between medicine and psychology students, Chi square $\left(\chi^{2}\right)$ with risk estimation (odds ratio) was used for contrasting the PCA variables and Student's $t$ of independent samples to contrast the dimensions of the OMI-M. In the risk estimation, the degree program (medicine or psychology) was used as an explanatory variable and the

Table 1

Perception of aggression and dangerousness

\begin{tabular}{|c|c|c|c|c|c|c|}
\hline & \multicolumn{2}{|c|}{$\begin{array}{c}\text { Medicine } \\
n=57\end{array}$} & \multicolumn{2}{|c|}{$\begin{array}{c}\text { Psychology } \\
n=58\end{array}$} & \multirow[b]{2}{*}{ Statistics } & \multirow{2}{*}{$\begin{array}{l}\text { Odds ratio } \\
(95 \% \mathrm{Cl})\end{array}$} \\
\hline & $n$ & $\%$ & $n$ & $\%$ & & \\
\hline \multicolumn{7}{|c|}{ Verbal aggression } \\
\hline Absent & 25 & 43.9 & 37 & 63.8 & \multirow{2}{*}{$\chi_{(1)}^{2}=4.59^{*}$} & 1.5 \\
\hline Present & 32 & 56.1 & 21 & 36.2 & & $(1.01-2.22)$ \\
\hline \multicolumn{7}{|c|}{ Self-directed aggression } \\
\hline Absent & 16 & 28.1 & 28 & 48.3 & \multirow{2}{*}{$\chi_{(1)}^{2}=4.96^{*}$} & 1.5 \\
\hline Present & 41 & 71.9 & 30 & 51.7 & & $(1.05-2.14)$ \\
\hline \multicolumn{7}{|c|}{ Aggression towards objects } \\
\hline Absent & 21 & 36.8 & 41 & 70.7 & \multirow{2}{*}{$\chi_{(1)}^{2}=13.25^{* * *}$} & 2.0 \\
\hline Present & 36 & 63.2 & 17 & 29.3 & & $(1.34-3.17)$ \\
\hline \multicolumn{7}{|c|}{ Hetero-directed aggression } \\
\hline Absent & 18 & 31.6 & 31 & 53.4 & \multirow{2}{*}{$\chi_{(1)}^{2}=5.62^{\star *}$} & \\
\hline Present & 39 & 68.4 & 27 & 46.6 & & $(1.07-2.21)$ \\
\hline \multicolumn{7}{|c|}{ Overall perception of aggression } \\
\hline Absent & 5 & 8.8 & 22 & 37.9 & \multirow[t]{2}{*}{$\chi_{(1)}^{2}=13.60^{\star * *}$} & 1.9 \\
\hline Present & 52 & 91.2 & 36 & 62.1 & & $(1.46-2.71)$ \\
\hline \multicolumn{7}{|c|}{ Perception of dangerousness } \\
\hline Absent & 23 & 40.4 & 48 & 82.8 & \multirow{2}{*}{$\chi_{(1)}^{2}=21.88^{* * *}$} & 2.9 \\
\hline Present & 34 & 59.6 & 10 & 17.2 & & $(1.68-5.25)$ \\
\hline
\end{tabular}

Note: ${ }^{*} p<.05 ;{ }^{* *} p<.01 ;{ }^{* * *} p<.001$. 
perception of the different types of aggression and danger as a variable outcome. The level of statistical significance was set at $p \leq .05$.

\section{RESULTS}

\section{Perception of aggression and dangerousness}

More than $60 \%$ of the students in both degree programs considered that the subject described in the vignette could be aggressive, although this percentage was higher in female medical students, who also had a greater perception of danger. In addition to the comparison statistics, greater risks of perception of aggression and dangerousness were observed in these students. For example, female medical students are twice as likely to perceive aggression towards objects by a person like the one described in the vignette as psychology students. Table 1 shows the frequencies and percentages of the perception of aggression, its four variants described in the PCA and the perception of dangerousness.

\section{Attitudes towards people with severe mental disorders}

Medical students showed higher scores in the areas of separatism, restriction, and stigmatization in comparison with psychology students, which is indicative of more negative attitudes towards mental illness on the part of the former. These results can be seen in Table 2 .

\section{DISCUSSION AND CONCLUSION}

The purpose of this study was to compare the stigmatizing attitudes and perception of aggression of female undergraduate medicine and psychology students towards people with schizophrenia.

Our results show that the concept of aggressiveness is a central aspect of the stereotype formed about individuals with schizophrenia (Angermeyer \& Matschinger, 1996).

Table 2

Attitudes toward people with schizophrenia

\begin{tabular}{|c|c|c|c|c|c|}
\hline \multirow[b]{2}{*}{ OMI-M } & \multicolumn{2}{|c|}{$\begin{array}{c}\text { Medicine } \\
n=57\end{array}$} & \multicolumn{2}{|c|}{$\begin{array}{c}\text { Psychology } \\
n=58\end{array}$} & \multirow[b]{2}{*}{ Statistics } \\
\hline & $M$ & $S D$ & $M$ & $S D$ & \\
\hline Separatism & 25.8 & 5.1 & 20.9 & 3.8 & $t_{(113)}=5.7^{* \star *}$ \\
\hline Stereotypes & 10.0 & 2.2 & 9.5 & 2.6 & $t_{(113)}=.9_{N S}$ \\
\hline Restriction & 9.35 & 2.2 & 8.4 & 2.8 & $t_{(113)}=1.9^{*}$ \\
\hline Benevolence & 17.6 & 2.4 & 16.9 & 3.3 & $t_{(113)}^{(113)}=1.3_{\mathrm{N.S}}$. \\
\hline Pessimistic prediction & 13.2 & 2.8 & 13.9 & 3.3 & $t_{(113)}=-1.1_{\mathrm{N} . \mathrm{S}}$ \\
\hline Stigmatization & 7.8 & 1.7 & 7.0 & 2.0 & $t_{(113)}=2.2^{*}$ \\
\hline
\end{tabular}

Note: ${ }^{*} p<.05 ;{ }^{* *} p<.01 ;{ }^{* * *} p<.001$
Although the clinical vignette presented makes no mention of aggressive or violent acts, the percentage of students from both degree courses who considered that the patient was violent was even higher than that reported in previous studies on the Mexican population (Fresán et al., 2010; Robles-García et al., 2013). The difference observed between the present study and community studies could be explained by the fact that only women were included in the study. It has been observed that women tend to report a higher perception of potentially aggressive behaviors, which is a reflection of the greater fear they feel towards them (Stuart \& Arboleda-Flórez, 2001). However, in the study conducted in Mexico, the comparisons by gender showed no differences related to the perception of aggression (Stuart \& Arboleda-Flórez, 2001). Due to the inconclusive findings regarding the perception of aggression and gender, it is important to conduct further studies that will more specifically evaluate the impact of gender on the perception of the aggression of patients with schizophrenia.

In general, a higher percentage of medical students perceived the patient as aggressive (in the four modalities: verbal, self-directed, aggression towards objects, and towards people) and dangerous. Since aggression and danger are a central part of stigma, some authors report that this belief leads to an increase in negative attitudes towards patients (Corrigan \& Watson, 2007). This proposal is supported by our results, in which medical students reported more negative attitudes towards patients with schizophrenia. Accordingly, they think that aggressive patients should not have the right to form a family, that they will be unlikely to have friendships, and that they should not form an integral part of the community to which they belong. Moreover, these conceptions, together with the perception that patients are persons with limited capacities, encourage greater social distancing (Crisp, Gelder, Rix, Meltzer, \& Rowlands, 2000), which has been defined as the desire not to establish a link or relationship with a person (Bowman, 1987) and has already been extensively described in the international literature (Economou, Richardson, Gramandani, Stalikas, \& Stefanis, 2009; Jorm \& Griffiths, 2008; Link et al., 1999; Marie \& Miles, 2008; Pescosolido et al., 2010).

Both the perception of aggression and dangerousness and the associated negative attitudes in this sample reflect the lower degree of understanding first year medical students could have in comparison with psychology students in relation to the experienced undergone by patients (Crisp et al., 2000). When the symptoms of the disease are described in a vignette, students' fears are exacerbated since these are unknown experiences, even though this vignette makes no mention of aggressive or violent behaviors by the patient (Link et al., 1999).

Some authors have reported that medical training may reinforce concepts that stigmatize patients (Ay, Save, \& Fidanoglu, 2006) due to the biological approach provided in 
the etiology and treatment of the main symptoms. However, training in the area of mental illness is not one of the factors that causes this effect nor does it explain the difference between medicine and psychology students, since all the students were in the first semesters of their professional training, when subjects related to psychopathology are included, particularly schizophrenia.

Psychology students probably have a less stigmatizing view of serious mental disorders such as schizophrenia, since from the start of their training, professional interests are directed towards areas related to mental health, whereas medical students still have in the early semesters a limited perception of the areas of study of mental health, since they are immersed in the different fields of study comprising medical training. However, a central point to be addressed is that medical students are the ones who, in the future, will be able to train as psychiatrists, and therefore will be more likely to come into direct contact with people affected by schizophrenia. If stigmatizing behaviors towards people with schizophrenia arise at the beginning of their medical training, it is essential to ensure that within the academic curriculum clear and objective information with a biopsychosocial approach to the disease is included from the beginning, and that the issue of stigma and attitudes toward the mentally ill is addressed. The aim is to reduce or eliminate stigmatizing beliefs and attitudes towards schizophrenia acquired prior to professional training.

One of the main limitations of this study is that recruitment was carried out at a single educational institution, making it impossible for the results to be generalized to populations of medicine and psychology students from different educational facilities. In the future, it will be necessary to undertake a longitudinal evaluation of the perception of the aggression and dangerousness posed by schizophrenia to confirm whether the information provided to students in the academic curriculum is useful in reducing negative attitudes towards the condition. It will also be important to increase the sample size in order to perform secondary analyses by academic year.

Knowledge about the attitudes of future mental health professionals towards schizophrenia will not only be useful for medical and psychology students during their training and future working lives, but will also increase the opportunities to provide timely specialized care for patients with schizophrenia by reducing the gap between the stigmatizing perception of their condition and the clinical reality of their enormous possibilities of achieving community rehabilitation and reintegration.

\section{Funding}

None.

\section{Conflict of interests}

The authors declare they have no conflict of interests.

\section{REFERENCES}

Angermeyer, M. \& Matschinger, H. (1996). The effect of violent attacks by schizophrenic persons on the attitude of the public towards the mentally ill. Social Science \& Medicine, 43(12), 1721-1728.

Arens, E., Berger, C., \& Lincoln, T. (2009). Stigmatisierung von Patienten mit Schizophrenie: Prägt das Studium die Einstellungen angehender Psychologen und Mediziner. Der Nervenarzt, 80(3), 329-339.

Ay, P., Save, D., \& Fidanoglu, O. (2006). Does stigma concerning mental disorders differ through medical education? A survey among medical students in Istanbul. Social Psychiatry and Psychiatric Epidemiology, 41(1), 63-67.

Bowman, J. T. (1987). Attitudes toward disabled persons: Social distance and work competence. Journal of Rehabilitation, 53(1), 41-44.

Corrigan, P. W. (2005). On the stigma of mental illness: Practical strategies for research and social change. Washington, DC: American Psychological Association.

Corrigan, P. \& Watson, A. (2007). The stigma of psychiatric disorders and the gender, ethnicity, and education of the perceiver. Community Mental Health Journal, 43(5), 439-458.

Crisp, A., Gelder, M., Rix, S., Meltzer, H., \& Rowlands, O. (2000). Stigmatisation of people with mental illnesses. The British journal of psychiatry, 177(1), 4-7.

Economou, M., Richardson, C., Gramandani, C., Stalikas, A., \& Stefanis, C. (2009). Knowledge about schizophrenia and attitudes towards people with schizophrenia in Greece. International Journal of Social Psychiatry, 55(4), 361-371.

Fernando, S., Deane, F., \& McLeod, H. J. (2010). Sri Lankan doctors' and medical undergraduates' attitudes towards mental illness. Social psychiatry and psychiatric epidemiology, 45(7), 733-739.

Feinstein, A. R. (1995). Clinical epidemiology: The architecture of clinical research. Statistics in Medicine, 14(11), 1263-1263.

Fresán, A., Robles-García, R., Saracco, R., \& Escamilla, R. (2010). Development and psychometric properties of a brief instrument to measure the stigma of aggressiveness in schizophrenia. Actas Españolas de Psiquiatría, 38(6), 340344.

Fresán, A., Robles-García, R., Cota, M., Berlanga, C., Lozano, D., \& Tena, A. (2012). Actitudes de mujeres estudiantes de psicología hacia las personas con trastornos mentales graves: Relación con la percepción de agresividad y peligrosidad. $\mathrm{Sa}$ lud Mental, 35(3), 215-223.

Fresán, A., Robles-García, R., Martínez, N., Berlanga, C., \& Vargas-Huicochea, I. (2012). Alfabetización sobre esquizofrenia en estudiantes de medicina. Sociedad Iberoamericana de Información Clínica, 19(3), 220-223.

Fresán, A., Tejero, J., Apiquian, R., Lóyzaga, C., García-Anaya, M., \& Nicolini, H. (2002). Aspectos penales y características clínicas de la criminalidad en la esquizofrenia. Salud Mental, 25(5), 72-78.

García-Silberman, S. (1998). Attitudes toward mental illness and psychiatry: Preliminary results. Salud Mental, 21, 40-50.

Goffman, E. (2009). Stigma: Notes on the Management of Spoiled Identity. New York: Simon \& Shuster.

Jones, E., Farina, A., Hastorf, A., Markus, H., Miller, D., \& Scott, R. (1984). Social stigma: The psychology of Marked Relationships. New York: WH Freeman.

Jorm, A. F. \& Griffiths, K. M. (2008). The public's stigmatizing attitudes towards people with mental disorders: How important are biomedical conceptualizations?. Acta Psychiatrica Scandinavica, 118(4), 315-321.

Link, B., Cullen, F., Frank, J., \& Wozniak, J. (1987). The social rejection of ex-mental patients: understanding why labels matter. American Journal of Sociology, 92(6), 1461-1500.

Link, B., Phelan, J., Bresnahan, M., Stueve, A., \& Pescosolido, B. (1999). Public conceptions of mental illness: Labels, causes, dangerousness, and social distance. American Journal of Public Health, 89(9), 1328-1333.

Magliano, L., Read, J., Sagliocchi, A., Oliviero, N., D’Ambrosio, A., Campitiello, F., ... Patalano, M. (2014). Social dangerousness and incurability in schizophrenia: Results of an educational intervention formedical and psychology students. Psychiatry Research, 219(3), 457-463.

Marie, D. \& Miles, B. (2008). Social distance and perceived dangerousness across four diagnostic categories of mental disorder. Australian \& New Zealand Journal of Psychiatry, 42(2), 126-133. 
Mental Health Foundation. (2000). Pull yourself together! A survey of the stigma and discrimination faced by people who experience mental distress. London: Mental Health Foundation.

Ng, P. \& Chan, K. (2000). Sex differences in opinion towards mental illness of secondary school students in Hong Kong. International Journal of Social Psychiatry, 46(2), 79-88.

Penn, D., Guynan, K., Daily, T., Spaulding, W., Garbin, C., \& Sullivan, M. (1994). Dispelling the stigma of schizophrenia: What sort of information is best? Schizophrenia bulletin, 20(3), 567-578.

Pescosolido, B., Martin, J., Long, J., Medina, T., Phelan, J., \& Link, B. (2010). A disease like any other"? A decade of change in public reactions to schizophrenia, depression, and alcohol dependence. American Journal of Psychiatry, 167(11), 1321-1330.

Robles-García, R., Fresán, A., Berlanga, C., \& Martínez, N. (2013). Mental illness recognition and beliefs about adequate treatment of a patient with schizophrenia: Association with gender and perception of aggressiveness-dangerousness in a community sample of Mexico City. International Journal of Social Psychiatry, 59(8), 811-818.
Rose, D., Thornicroft, G., Pinfold, V., \& Kassam, A. (2007). 250 labels used to stigmatise people with mental illness. BMC Health Services Research, 7(1), 97.

Schulze, B. \& Angermeyer, M. (2003). Subjective experiences of stigma. A focus group study of schizophrenic patients, their relatives and mental health professionals. Social Science \& Medicine, 56(2), 299-312.

Steadman, H. J., Mulvey, E. P., Monahan, J., Robbins, P. C., Appelbaum, P. S., Grisso, T., ... Silver, E. (1998). Violence by people discharged from acute psychiatric inpatient facilities and by others in the same neighborhoods. Archives of General Psychiatry, 55(5), 393-401.

Stuart, H. \& Arboleda-Flórez, J. (2001). Community attitudes toward people with schizophrenia. The Canadian Journal of Psychiatry, 46(3), 245-252.

Thornicroft, G. (2006). Shunned: Discrimination against people with mental illness. Oxford: Oxford University Press.

Yang, L., Kleinman, A., Link, B., Phelan, J., Lee, S., \& Good, B. (2007). Culture and stigma: adding moral experience to stigma theory. Social Science \& Medicine, 64(7), 1524-1535. 